\title{
ANALISIS STRATEGI PENANGANAN PEMBIAYAAN MURABAHAH BERMASALAH DI KOPERASI SIMPAN PINJAM DAN PEMBIAYAAN SYARIAH PERAMBABULAN CIREBON
}

\author{
Risnawati dan Muhammad Qoes Atieq \\ Institut Agama Islam Negeri Syekh Nurjati Cirebon \\ Email: risna.risnawati1229@gmail.com dan muhammadqoesatieq@gmail.com
}

\begin{abstract}
This study in save and credit Cooperatives and Sharia Financing Perambabulan aims to determine the strategy for handling problematic Murabaha financing in savings and loan cooperatives and forgeries sharia financing. The research method used is a qualitative method with data collection through structured interviews, field observations, and documentation. The results of the study found that the factors causing Murabaha financing problems in Kamburan Perambabulan are internal factors (less optimal analysis of files, lack of further surveys, lack of maximum running the SOP of Financing) and external factors (dishonesty and unsafe attitude of members, declining business efforts from members, the presence of bad faith, members who procrastinate, the existence of an accidental element such as flood fires, and other natural disasters). The strategies are Informing by telephone, Providing warning letters, reconditioning and execution of collateral. Efforts to overcome the problematic financing that is, must implement the SOP correctly, Maximize the principle of 5C (Character, Capacity, Capital, Collateral, Condition), carry out adequate segregation of duties, apply the principle of caution, and improve employee skills.
\end{abstract}

Keywords: Problem financing, Murabaha financing, and KSPPS Perambabulan Strategy.

\begin{abstract}
Abstrak
Penelitian pada Koperasi Simpan Pinjam dan Pembiayaan Syariah Perambabulan ini bertujuan untuk mengetahui strategi penanganan pembiayaan murabahah bermasalah di koperasi simpan pinjam dan pembiayaan syariah perambabulan. Metode penelitian yang digunakan adalah metode kualitatif dengan pengambilan data melalui wawancara terstruktur, observasi lapangan dan dokumentasi. Hasil penelitian yang didapatkan bahwa Faktor penyebab pembiayaan murabahah bermasalah di KSPPS Perambabulan yaitu terdapat faktor internal (kurang maksimal menganalisis berkas, kurang adanya survey lebih lanjut, kurang maskimal menjalankan SOP Permbiayaan) dan faktor eksternal (ketidak jujuran dan sikap tidak amanah dari anggota, menurunnya usaha dari anggota, adanya itikad yang tidak baik, anggota yang menunda-nunda, adanya unsur ketidak sengajaan seperti kebakaran kebanjiran, dan bencana alam lainnya). Strategi penanganannya yaitu Menginformasikan melalui telephone, Memberikan surat peringatan, (rescheduling), Persyaratan ulang (reconditioning) dan eksekusi jaminan. Upaya-upaya untuk menanggulangi terjadinya pembiayaan yang bermasalah yaitu, wajib melaksanakan SOP dengan benar, Memaksimalkan prinsip 5C (Character, Capacity, Capital, Collateral, Condition), melakukan pemisahan tugas yang memadai, menerapkan prinsip kehati-hatian, dan meningkatkan skill karyawan.
\end{abstract}

Kata Kunci: Pembiayaan Bermasalah, Pembiayaan Murabahah, dan Strategi KSPPS Perambabulan. 


\section{PENDAHULUAN}

Koperasi syariah merupakan salah satu gerakan ekonomi yang kegiatannya berlandaskan pada prinsip koperasi yang berasaskan kekeluargaan serta menerapkan prinsip syariah. Berdasarkan filosofi syariahnya yaitu adanya prinsip profit sharing atau bagi hasil dan interest free, yang melarang penerapan bunga dalam semua transaksi keuangan. Konsep tersebut merupakan salah satu kelebihan koperasi syariah di bandingkan dengan koperasi konvensional.

Pada dasarnya koperasi syariah mempunyai beberapa persamaan pengertoannya terkait kegiatan usahanya yaitu yang bergerak dalam bidang pembiayaan, investasi, dan simpana yang sesuia dengan akad bagi hasil. Persamaan tersebut lebih dikenal dengan koperasi jasa keuangan syariah. Secara operasional dan kegiatan koperasi syariah produk-produknya mempunyai cara kerja yang hampir sama tapi dengan istilah lain, seperti murabahah, mudharabah, dll. Selain adanya perubahan nama, pada sistem operasionalnya pun berubah yang awalnya konvensional menjadi sistem syariah dengan sesuia aturan-aturan agama islam atau sesuai syariah.

Koperasi Simpan Pinjam dan Pembiayaan Syariah (KSPPS) Perambabulan adalah sebuah lembaga keuangan yang berawal dari persatuan kelompok penjahit yang ada di desa Babadan, Mayung, Buyut dan Pangkalan dengan kegiatan awal arisan bulanan. Setiap tahun perkembangan KSPPS Perambabulan semakin meningkat, sehingga kegiatan usaha yang dilakukan yaitu menghimpun dana dari anggota berupa tabungan, deposito dan kemudian menyalurkan kepada anggota yang memerlukan dana dalam bentuk pembiayaan. Salah satu produk jasa pembiayaan KSPPS Perambabulan adalah pembiayaan murabahah. Murabahah adalah suatu akad jual beli barang pada harga asal ditambah degan margin (keuntungan) dan kedua belah telah menyepakatinya, slanjutnya penjula terlebih dahulu memberikan informasi terkait dengan harga perolehan kepada pembeli.
Akad murabahah merupakan salah satu produk pembiayaan yang sering digunakan oleh KSPPS Perambabulan karena karakteristiknya yang menguntungkan dan mudah dalam penerapannya.

Analisa kelayakan usaha kepada calon penerima pembiayaan sangat diperlukan dalam menilai perkembangan dan kelangsungan usaha nasabah agar tidak menimbulkan suatu pembiayaan yang bermasalah. Pada kenyataannya dalam menjalankan analisis pembiayaan dengan cara menganalisis setiap permohonan pembiayaan resiko terjadinya pembiayaan tersebut macet bisa saja terjadi

Pembiayaan bermasalah adalah pembiayaan yang terjadi ketidaklancaran dari pihak koperasi kepada anggota yang tidak bisa atau tidak mau bertanggungjawab untuk membayar kembali dana yang dipinjamnya secara penuh saat jatuh tempo ataupun sesudah masa jatuh temponya. Untuk mengatasi pembiayaan bermasalah diperlukan suatu penanganan dan penyelesaian oleh pihak koperasi sebagai langkah penyelematan agar terhindar dari kerugian. Dalam faktor pembiayaan bermasalah pihak koperasi syariah perlu melakukan evaluasi dengan cara mengangani masalah tersebut sehingga tidak akan menimbulkan kerugian. Penanganan yang dilakukan yaitu dengan cara memberikan keringanan berupa jangka waktu atau jumlah angsuran terutama bagi pembiayaan yang terkena musibah maupun dengan melakukan penyitaan bagi anggota yang melakukan pembiayaan dengan sengaja tidak membayarkan kewajibannya.

Berdasarkan latar belakang tersebut maka diperoleh perumusan masalah dalam penelitian ini yaitu: (1) Apa saja faktor yang menjadi penyebab tejadinya pembiayaan murabahah bermasalah? (2) Strategi apa saja yang digunakan oleh pihak KSPPS Perambabulan dalam penanganan pembiayaan murabahah bermasalah? (3) Upaya apa saja yang diterapkan dalam menanggulangi pembiayaan murabahah bermasalah?

Dengan demikian tujuan penelitian ini adalah untuk mengetahui strategi 
penanganan pembiayaan murabahah bermasalah di koperasi simpan pinjam dan pembiayaan syariah perambabulan.

\section{LITERATURE REVIEW}

Dalam menentukan penelitian, terlebih dahulu peneliti membandingkan dengan penelitian terdahulu sebagai rujukan materi yang akan dibahas. Terdapat beberapa penelitian yang berkaitan dengan penelitian yang akan dilakukan adalah sebagai berikut:

1. (Novitasari), (2016) dalam penelitiannya yang berjudul "Analisis Penanganan Pembiayaan Bermasalah Pada Akad Murabahah Di BMT Al-Hikmah Ungaran Cabang Gunungpati”. Penelitian ini menggunakan metode penelitian kualitatif. Berdasarkan penelitian tersebut dapat ditarik kesimpulan bahwasanya pembiayaan bermasalah tersebut berasal dari beberapa faktor, yaitu nasabah yang memppunyai kebutuhan yang mendesak, kurangnya amanah dari nasabah, terjadinya bencana alam dan kebijakan pemerintah yang kurang memihak, serta kurang telitinya pihak BMT dalam menganalisis dan menyeleksi dokumendokumen dari para nasabah atau anggota dan juga kurangnya pengawasan yang dilakukan pihak BMT terhadap jalannya usaha. Apabila hal tersebut terjadi yaitu pembiayaan yang bermasalah, penanganan yang dilakukan oleh pihak BMT pertama kali adalah dengan pendekatan persuasif berupa musyawarah, serta dengan cara rescheduling, reconditioning, dan restructuring, bahkan bisa sampai ke cara liquidation (penyitaan jaminan) apabila diperlukan.

2. (Nasrullah), (2017) dalam penelitiannya yang berjudul "Strategi Penyelesaian Pembiayaan Murabahah Bermasalah Di Koperasi Simpan Pinjam dan Pembiayaan Syariah Bina Insan Mandiri (KSPPS BIM) Gondangrejo Karanganyar". Adapun analisis penelitian ini menggunakan metode deskriptif evaluatif. Berdasarkan penelitian tersebut mennjukkan bahwa faktor-faktor yang berkaitan dengan pembiayaan bermsalah adalah (1) penurunan usaha dari nasabah, (2) banyak berhutang di tempat lain, (3) adanya itikad kurang baik, (4) adanya keterlambatan yang dilakukan oleh kolega bisnis dalam dal pengiriman uang, (5)kurang cakap dalam mengelola usahanya, (6) kebijakan pemerintah, (7) bencana alam, (8) penundaan pembayaran, (9) kurangnya ketelitian pihak BMT dalam melakukan pembiayaan, (10) tidak meneliti berkas nasabah secara maksimal dan tidak mensurvey, (11) terlalu mudah dalam memberikan pembiayaan, (12) kurangnya kmunikasi dengan nasabah. Adapun strategi pembiayaan bermasalah adalah (1) strategi rescheduling, (2) strategi reconditioning, (3) strategi penyitaan/eksekusi jaminan. kemudian upaya penanggulangan agar tidak terjadi pembiayaan bermasalah adalah (1) melaksanakan SOP dengan benar dan melakukan survey dengan memaksimalkan prinsip 5C, (2) melakukan pemisahan tugas yang memadai, (3) membuat rekening tabungan bagi nasabah pembiayaan, (4) melihat prospek kedepan usaha nasabah, (5) menerapkan prinsip kehati-hatian, (6) menolak pengajuan pembiayaan oleh nasabah yang sudah di blacklist, (7) meningkatkan mutu pelayanan, (8) meningkatkan skill karyawan, (9) meningkatkan pengawasan internal.

3. (Majid), (2015) dalam penelitiannya yang berjudul "Analisis Penanganan Pembiayaan Murabahah Bermasalah Di BMT EL Amanah Kendal". Penelitian ini merupakan kajian eksploratif sekaligus evaluatif terhadap masalah penanganan pembiayaan bermasalah dengan pendekatan kualitatif. Hasil penelitian menunjukkan bahwa penanganan yang dilakukan di BMT El Amanah menggunakan strategi rescheduling, reconditioning, dan eksekusi.

4. (Tanjung), (2015) dalam penelitiannya yang berjudul "Penanganan Pembiayaan Bermasalah Di BMT Amanah Mulia Magelang". Jenis penelitian ini adalah 
penelitian lapangan, data-data penelitian ini berupa data kualitatif yang terdiri dari data primer dan sekunder. Pada penelitian tersebut menghasilkan beberapa kesimpulan terkait dengan faktor-faktor yang memengaruhi pembiayaan bermasalah yaitu sebagai berikut : 1) Pada faktor internal terdapat beberapa karyawan yang tidak cakap dan kinerja kurang, 2) adanya kedeketan dengan keluarga, 3) penganalisisan yang tidak teliti yang dilakukan oleh petugas terhadap anggota, sedangkan faktor ekstrenal adalah sebagai berikut; 4) kurang baiknya kondisi perekonomian, 5) menjamurnya persaingan usaha, 6) bahan baku yang sulit didapatkan, 7) tidak adanya i'tikad baik dari anggota untuk membayar kewajiban pinjaman, dan 8) terjadinya bencana alam.

Hasil yang diperoleh dari penelitian ini adalah: pertama, faktor-faktor yang menyebabkan terjadinya pembiayaan bermasalah di BMT Amanah Mulia Magelang terdiri dari faktor internal (karyawan belum cakap, faktor kedekatan dengan keluarga, kurang ketelitian petugas dalam menganalisis anggota) dan faktor eksternal (kondisi perekonomian yang kurang baik, banyaknya persaingan usaha, sulitnya bahan baku, keenggananan anggota dalam kewajiban membayar pinjaman atau anggota beritikad tidak baik, dan terjadinya bencana alam yang tak terduga. Kesimpulan selanjutnya dalam menyelesaikan pembiayaan bermasalah, BMT Amanah Mulia Magelang setelah melakukan upaya pencegahan, analisa sebab pembiayaan bermasalah, dan menggali potensi pinjaman, kemudian melakukan tindakan rescheduling (penjadwalan kembali), reconditioning (persyaratan kembali), penyelesaian melalui jaminan (eksekusi), dan write off final (peghapusan bukuan dan penghapustagihan).

5. (Rahayu), (2018) dalam penelitiannya yang berjudul "Strategi Penanganan Pembiayaan Bermasalah Pada Produk Pembiayaan Murabahah Di KSPPS BMT
Walisongo Semarang". Metode yang digunakan dalam penelitian ini adalah dengan menggunakan metode penelitian kualitatif dengan analisa deskriptif. Hasil penelitian ini menunjukkan bahwa: ada dua faktor yang menyebabkan terjadinya pembiayaan bermasalah yaitu faktor internal dan faktor eksternal. Faktor internal penyebab masalah pembiayaan yaitu lemahnya petugas dalam menganlisis pembiayaan, lemahnya supervisor dalam menganani pembiayaan, ketidaktelitian petugas BMT, lemahnya agunan, kurangnya kebijakan-kebijakan dalam pembiyaaan, dan banyak petugas yang melakukan kecurangan. Sedangkan faktor internal nasabah yaitu karakter nasabah yang tidak bertanggungjawab, nasabah yang tidak teliti, nasabah mengalami musibah yang tidak diprediksi, lemahnya manajemen dari nasabah dalam pembiayaan. Selanjutnya faktor eksternal yaitu situasi ekonomi yang tidak pasti, sistem politik pemerintah yang tidak mendukung, dan bencana alam yang terjadi. Kedua, strategi penanganan pembiayaan bermasalah dengan menggunakan rescheduling/ penjadwalan kembali, reconditioning/ persyaratan kembali, dan liquidation/ penyitaan jaminan.

\section{METODE PENELITIAN}

Metode penelitian yang digunakan dalam penelitian ini, yaitu:

1. Jenis Penelitian

Penelitian ini merupakan jenis penelitian kualitatif. Adapun penelitan kualitatif adalah suatu prosedur penelitian yang menghasilkan data deskriptif berupa katakata tertulis maupun lisan dari orangorang dan perilaku yang dapat diamati (Meleong, 2002).

2. Sumber Data

Sumber data dalam penelitian ini adalah kumpulan pengamatan penulis terhadap fenomena-fenomena, data-data, bahan kajian penelitian terdahulu, serta jurnaljurnal ilmiah yang terkait dengan judul yang diteliti, yang terdiri dari: 
a. Data Primer

Data primer adalah data yang diperoleh langsung dari sumber obyek penelitian dan berhubungan langsung degan permasalahan yang diteliti. Data tersebut diperoleh langsung dari lapangan. Adapun data primer dalam penelitian ini dilakukan dengan melalui wawancara dengan manager dan karyawan KSPPS Perambabulan, dan observasi langsung terhadap proses penanganan pembiayaan bermasalah dan data-data langsung dari KSPPS Perambabulan.

b. Data Sekunder

Data sekunder adalah data yang diperoleh dari kantor, buku-buku (kepustakaan), atau pihak lain yang mempunyai data yang terkait erat dengan obyek dan permasalahan yang sedang diteliti. Adapun data sekunder dalam penelitian ini adalah studi terhadap karya tulis ilmiah, jurnal, dan dokumen yang berkaitan degan topik yangs sedang diteliti, ataupun obyek penelitian yakni KSPPS Perambabulan.

3. Metode pengumpulan Data

Dalam penelitian ini, peneliti menggunakan metode pengumpulan data sebagai berikut:

a. Wawancara

Merupakan teknik pengumpulan data dengan cara Tanya jawab yang dikerjakan secara sistematis dan berlandaskan pada tujuan, masalah, dan hipotesis penelitian (Tika, 2006). Dalam wawancara ini teknik yang digunakan dalam pengumpulan datadata yang diperlukan adalah dengan mengajukan pertanyaan-pertanyaan yang telah disusun secara sistematis dan analisis. Pertanyaan-pertanyaan ini diajukan langsung dalam wawancara yang mendalam dengan pimpinan KSPPS Perambabulan.

b. Observasi

Merupakan pengamatan atau teknik pengumpulan data yang mempunyai ciri spesifik yang tidak terbatas pada orang saja. akan tetapi juga fenomenafenomena yang dapat diamati oleh panca indera. Teknik ini digunakan bila berkenaan dengan perilaku manusia, proses kerja, gejala-gejala alam dan bila obyek yang diteliti tidak terlalu besar (Sugiyono, 2012). Dalam hal ini penulis melakukan pengamatan secara langsung terhadap prosesi penanganan pembiayaan bermasalah dilapangan.

c. Dokumentasi

Dalam penelitian ini, peneliti memanfaatkan arsip atau data-data yang akurat berhubungan dengan KSPPS Perambabulan sebagai penunjang penelitian.

\section{KONSEP DASAR}

\section{Pengertian Murabahah}

Murabahah secara etimologi berasal dari kata ribhun (keuntungan). Sedangkan secara terminology istilah murabahah didefinisikan sebagai prinsip dalam jual beli yang mana harga jual yang diberikan terdiri dari harga pokok barang yang ditambahkan dengan nilai keuntungannya (ribhun) dengan catatatn ada kesepakatan antara kedua belah pihak (Sutedi, 2009).

Seperti yang tertuang dalam fatwa DSN MUI No.4/DSN-MUI/IV/2000, bahwa dalam rangka membantu masyarakat guna melangsungkan dan meningkatkan kesejahteraan, maka bank syariah perlu memiliki fasilitas murabahah bagi yang memerlukannya, yaitu menjual suatu barang dengan menegaskan harga belinya kepada pembeli, dan pembeli membayarnya dengan harga yang lebih sebagai laba (Irham \& Sholihin, 2010).

\section{Pengertian Pembiayaan Bermasalah}

Pembiayaan adalah pengadaan uang atau berupa tagihan yang berdasarkan persetujuan atau kesepakatan antara pihak bank dengan pihak nasabah, dan nasabah bertanggungjawab untuk mengembalikan dana atau tagihan tersebut apabila jangka waktunya sudah ditetapkan dengan imblan beruba bagi hasil (Kasmir, 2002). 
Pembiayaan bermasalah adalah pembiayaan yang diklasifikasikan pembayarannya tidak lancar yang dilakukan oleh anggota yang bersangkutan. Pembiayaan bermasalah harus secepatnya diselesaikan agar tidak terjadi kerugian yang lebih besar kepada anggotanya. Sehingga dalam memberikan pembiayaan terlebih dahulu harus melakukan analisis pembiayaan yang seksama, cermat dan teliti dalam mencari data yang actual dan akurat, sehingga tidak akan keliru dalam mengambil keputusan (Yaya \& Erlangga, 2014).

Pembiayaan bermasalah yaitu pembiayaan terkait dengan kualitasnya berdasarkan atas resiko dan kemungkinan terhadap kondisi dan ketaatan nasabah pembiayaan untuk memenuhi kewajiban pembayaran bagi hasil dan juga melunasi tagihan pembiayaan. Menurut Khasmir (2013) penilaian kualitas pembiayaan dibedakan menjadi:

1. Lancar

Apabila pembayaran angsuran dan margin tepat waktu, tidak ada tunggakan, sesuai dengan persyaratan akad, selalu menyampaikan laopran keuangan secara teratur dan akurat, secara dokumentasi perjanjian piutang lengkap dan pengikatan agunan kuat.

2. Dalam Perhatian Khusus

Apabila terdapat tunggakan pembayaran angsuran pokok dan atau margin sampai degan 90 hari. Akan tetapi selalu menyampaikan laporan keuangan secara teratur dan akurat, dokumentasi perjanjian piutang lengkap dan pengikatan agunan kuat, serta pelanggaran terhadap persyaratan perjanjian piutang tidak prinsipil.

3. Kurang Lancar

Apabila terdapat tunggakan pembiayaan angsuran pokok dan atau margin yang telah melewati 90 hari sampai 180 hari, penyampaian laporan keuangan tidak secara teratur dan meragukan, dokumentasi perjanjian piutang kurang lengkap dan pengikatan agunan kuat. Terjadi pelanggaran terhadap persyaratan pokok perjanjian piutang, dan berupaya melakukan perpanjangan piutang untuk menyembunyikan kesulitan keuangan.

4. Diragukan

Apabila terjadi tunggakan pembayaran angsuran pokok dan atau margin yang telah melewati 180 hari sampai dengan 270 hari. Nasabah tidak menyampaikan informasi keuangan atau tidak dapat dipercaya, dokumentasi perjanjian piutang tidak lengkap dan pengikatan agunan lemah serta terjadi pelanggaran yang prinsipil terhadap persyaratan pokok perjanjian piutang.

5. Macet

Apabila terjadi tunggakan pembayaran angsuran pokok dan atau margin yang telah melewati 270 hari, dan dokumetasi perjanjian piutang dan pengikatan agunan tidak ada.

\section{Analisis Pembiayaan pada Koperasi Syariah}

Dalam melakukan penilaian permohonan pembiayaan harus memperhatikan beberapa prinsip utama yang berkaitan dengan kodisi secara keseluruhan calon anggota. Prisip tersebut dikenal dengan prinsip 5C, yaitu:

a. Character

Yaitu penilaian terhadap karakter atau kepribadian calon penerima pembiayaan dengan tujuan untuk memperkirakan kemungkinan bahwa penerima pembiayaan dapat memenuhi kewajibannya.

b. Capacity

Yaitu penilaian secara subjektif tentang kemampuan penerima pembiayaan untuk melakukan pembayaran. Kemampuan diukur dengan catatan prestasi penerima pembiayaan di masa lalu yang didukung dengan pengamatan dilapangan atas sarana usahanya seperti toko, karyawan, alatalat, pabrik serta metode kegiatan.

c. Capital

Yaitu penilaian terhadap kemampuan modal yang dimiliki oleh calon penerima pembiayaan yang diukur dengan posisi perusahaan secra keseluruhan yang 
ditunjukkan oleh rasio finansial dan penekanan pada komposisi modalnya.

\section{d. Collateral}

Yaitu jaminan yang dimiliki calon penerima pembiayaan. Penilaian ini bertujuan untuk lebih meyakinkan bahwa jika suatu resiko kegagalan pembayaran tercapai terjadi, maka jaminan dapat dipakai sebagai pengganti dari kewajiban.

e. Condition

Yaitu melihat kondisi ekonomi yang terjadi di masyarakat secara spesifik melihat adanya keterkaitan dengan jenis usaha yang dilakukan oleh calon penerima pembiayaan. Hal tersebut karena kondisi eksternal berperan besar dalam proses berjalannya usaha calon penerima pembiayaan (Kasmir, Analisis Laporan Keuangan, 2009).

\section{Faktor Penyebab Pembiayaan Bermasalah}

Pembiayaan bermasalah yang ada di lembaga keuangan syariah mempunyai beberapa penyebab yang terdiri dari faktor internal, faktor eksternal dan kondisi lingkungan yang akan dibahas sebagai berikut:

a. Faktor internal

Faktor internal koperasi syariah adalah penyumbang terbesar dalam menumbuhkan pembiayaan bermasalah. Pembiayaan bermasalah dapat diminimalisir melalui pemahaman petugas pembiayaan secara benar dan dilengkapi dengan prosedur kerja yang menjadi acuan petugas dalam merealisasikan pembiayaan koperasi syariah kepada anggotanya.
1) Kejujuran;
2) Pengetahuan;
3) Sikap;
4) Keterampilan;
5) Sistem operasional dan prosedur.

b. Faktor eksternal

Ada 4 faktor penting yang harus diperhatikan terhadap calon penerima pembiayaan antara lain (Buchori, 2012):

1) Karakter calon penerima pembiayaan.

2) Side streaming penggunaan dana.
3) Peningkatan pola konsumsi dan gaya hidup.

4) Memprioritaskan kepentingan lain.

c. Kondisi lingkungan

1) Kondisi alam.

2) Kebijakan pemerintah.

3) Demonstrasi.

4) Kendala musim.

\section{Penanganan Pembiayaan Bermasalah}

Penanganan pembiayaan (restrukturisasi pembiayaan) adalah istilah teknik yang bisa digunakan pada kalangan perbankan terhadap upaya dan langkah-langkah yang dilakukan oleh bank dalam mengatasi pembiayaan bermasalah.

Restrukturisasi pembiayaan adalah upaya yang akan dilakukan oleh bank dalam rangka akan membantu nasabah agar dapat menyelesaikan kewajibannya terhadap bank, antara lain melalui penjadwalan kembali (rescheduling), persyaratan kembali (reconditioning), dan penataan kembali (restructuring). Dari uraian tersebut, pembiayaan bermasalah berdasarkan prinsip syariah antara lain:

a. Penjadwalan kembali (rescheduling)

Penjadwalan kembali (rescheduling) adalah perubahan jadwal pembayaran kewajiban seorang nasabah atau jangka waktu sesuai yang sudah disepakati.

b. Persyaratan kembali (reconditioning)

Persyaratan kembali (reconditioning) adalah perubahan sebagian atau seluruh persyaratan pembiayaan tanpa menambah sistem pokok kewajiban kepada nasabah yang harus dibayarkan oleh bank, diantaranya yaitu:

1) Perubahan jadwal pembayaran.

2) Perubahan jangka waktu.

3) Perubahan jumlah angsuran.

4) Pemberian potongan.

c. Penataan kembali (restructuring)

Penataan kembali (restructuring) adalah perubahan pada persyaratan pembiayaan, antara lain yaitu (Z, 2012):

1) Konversi akad pembiayaan.

2) Konversi pembiayaan menjadi surat berharga syariah berjangka waktu menengah. 
3) Konversi pembiayaan menjadi penyertaan modal sementara pada nasabah yang dapat disertai degan rescheduling atau reconditioning.

\section{PEMBAHASAN DAN DISKUSI}

\section{Ruang Lingkup KSPPS Perambabulan}

Koperasi Syariah Perambabulan adalah sebuah lembaga keuangan yang berawal dari persatuan kelompok penjahit untuk meningkatkan kemampuan mereka dalam teknik menjahit, kemudian mereka membuka kegiatan arisan anggota. Tepat pada tanggal 1 januari 1996 membentuk Lembaga Ekonomi Produktif Masyarakat Mandiri (LEPMM) dan diberi nama Perambabulan. Singkatan dari Perambabulan yaitu Persatuan Remaja Penjahit Desa Mayung, Babadan, Buyut dan Pangkalan. Ketika berbadan hukum dan berpola syariah nama koperasi menjadi Koperasi Simpan Pinjam Syariah (KSPS) Perambabulan Al Qomariyah. Pada bulan Desember 2015, karena kepatuhan lembaga terhadap peraturan yang dikeluarkan pemerintah berkaitan dengan perkoperasian maka nama koperasi ini menjadi Koperasi Simpan Pinjam dan Pembiayaan Syariah (KSPPS) Perambabulan.

Koperasi Simpan Pinjam dan Pembiayaan Syariah (KSPPS) Perambabulan bergerak dalam sektor jasa keuangan syariah yang memiliki 2 jenis produk yaitu produk simpanan dan produk Pembiayaan dimana produk-produk yang dijalankan berdasarkan prinsip syariah. Adapun bidang jasa lain yang dijalankan, seperti pembayaran rekening listrik dan token, pembayaran speedy, iuran BPJS, Pembayaran Pajak Bumi dan Bangunan (PBB), angsuran kredit kendaraan, ATM MINI (tarik tunai ATM BRI dan transfer ke semua bank), dan lain-lain. Selain memiliki produk simpanan dana, penyaluran dana, dan bidang jasa, KSPPS Perambabulan mengelola baitul maal yaitu menerima dan menyalurkan dana zakat, infaq, shodaqoh dan dana sosial lainnya.

\section{Produk-produk KSPPS Perambabulan}

Produk simpanan yang ada di KSPPS Perambabulan yakni: Simpanan Pokok, Simpanan Wajib, TAMASKOP (Tabungan Masyarakat Koperasi), Tahara dan Taqorub (Tabungan Hari Raya dan Qurban), TAKOPNAS (Tabungan Koperasi anak sekolah), dan SIMJAKOP (Simpanan Berjangka Koperasi/Deposito). Produk simpanan ini dikelola menggunakan prinsipprinsip syariah yaitu dengan akad Mudharabah, dimana pihak KSPPS Perambabulan dapat mengelola dana anggota untuk usaha produktif dan halal. Sedangkan anggota akan mendapatkan imbalan bagi hasil.

Produk pembiayaan (penyaluran) dana terdiri dari: Pertama Pembiayaan Murabahah dimana pembiayaan yang diberikan kepada anggota/calon anggota yang membutuhkan barang-barang modal kerja, investasi atau barang-barang konsumsi lainnya. Dan yang Kedua yaitu Pembiayaan Musyarokah yang merupakan pembiayaan modal kerjasama usaha antar anggota/calon anggota dengan KSPPS Perambabulan dimana KSPPS menginvestasikan dananya dalam waktu terbatas. Dan investasi tersebut KSPPS Perambabulan memperoleh bagi hasil dari usaha yang dibiayai tersebut. Bagi hasil dapat dibayar setiap bulan atau sekaligus diakhir masa perjanjian.

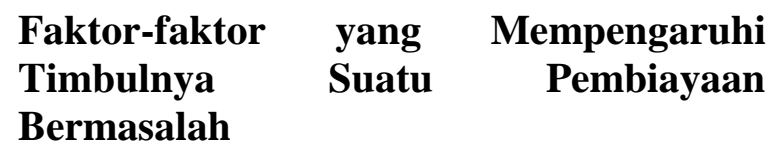

Faktor-faktor yang mempengaruhi timbulnya suatu pembiayaan bermasalah adalah: faktor internal atau dari pihak KSPPS Perambabulan yaitu kurang teliti dalam proses analisis calon penerima pembiayaan, kurang maksimal dalam meneliti dan menganalisis berkas calon penerima pembiayaan, kurangnya komunikasi dengan penerima pembiayaan, kurang adanya pengawasan atau survey lebih lanjut dari pihak KSPPS Perambabulan setelah dicairkan pembiayaan murabahah. Sedangkan faktor eksternal yang berasal dari penerima pembiayaan yaitu adanya ketidak 
jujuran dan sikap tidak amanah dari anggota, menurunnya usaha dari anggota, adanya itikad yang tidak baik, anggota yang menunda-nunda pembayaran padahal ia mampu, adanya unsur ketidak sengajaan dari anggota yang sedang dalam musibah seperti kebakaran kebanjiran, dan bencana alam lainnya.

\section{Strategi Penanganan KSPPS Perambabulan}

Strategi penanganan KSPPS Perambabulan dalam pembiayaan murabahah bermasalah:

a. Menginformasikan kepada penerima pembiayaan mengenai jatuh tempo yang sudah terlewat melalui telephone;

b. Memberikan surat peringatan 1, 2, dan 3;

c. Setelah proses itu pihak KSPPS Perambabulan terus memberikan jalan keluar dengan cara kekeluargaan, seperti

1) Penjadwalan kembali (rescheduling) yaitu degan perpanjangan waktu pembiayaan sehingga jumlah setiap bulan angsurannya menjadi turun dan perpanjangan jangka waktu angsuran, yang semula angsuran 1 bulan menjadi 2 bulan.

2) Persyaratan ulang (reconditioning) yaitu perubahan pesyaratan yang dibuat kembali sesuai dengan permasalahan yang sedang dihadapi penerima pembiayaan, seperti permintaan jaminan kembali.

3) Apabila selama 3 bulan berturut-turut penerima pembiayaan tersebut belum bisa melunasi kewajibannya dalam melakukan pembayaran, maka dari pihak KSPPS Perambabulan akan melakukan eksekusi jaminan. cara ini dilakukan apabila anggota sudah benar-benar tidak mampu lagi untuk membayar kewajiba angsurannya. Proses penyitaan jaminan tentu dengan persetujuan dari anggota, pihak KSPPS Perambabulan memberikan pilihan dalam penjualan jaminan tersebut apakah anggota sendiri yang akan menjual barangnya atau pihak KSPPS Perambabulan yang melakukan penjualan. Kemudian dari hasil penjualan jaminan tersebut digunakan untuk pelunasan angsuran pembiayaan, tetapi apabila jaminan dijual oleh pihak KSPPS Perambabulan dan terdapat uang sisa pelunasan pembiayaan akan dikembalikan kepada pemilik jaminan tersebut.

\section{Upaya Pencegahan untuk Menanggulangi Pembiayaan Murabahah Bermasalah}

Upaya pencegahan untuk menanggulangi pembiayaan murabahah bermasalah di KSPPS Perambabulan, yaitu:

a. Wajib melaksanakan SOP dengan benar, termasuk memeriksa kelengkapan permohonan pembiayaan.

b. Memaksimalkan prinsip 5C yaitu:

1) Character atau keadaan pribadi dan keluarga tentang kepatuhan memenuhi kewajiban-kewajibannya, seperti ketepatan membayar listrik, pajak, dan lain sebagainya.

2) Capacity atau kapasitas usaha yang dimiliki pemohon pembiayaan.

3) Capital atau permodalan yaitu modal yang ditanamkan serta sarana usaha yang dimiliki pemohon pembiayaan.

4) Collateral atau peyediaan jaminan, yaitu kekayaan yang dimiliki pemohon pembiayaan untuk bisa dijadikan sebagai jaminan.

5) Condition atau kondisi ekonomi berupa prospek usaha yang dilakukan pemohon pembiayaan.

c. Melakukan Pemisahan tugas yang memadai

d. Menerapkan prinsip kehati-hatian dalam memberikan pembiayaan.

e. Meningkatkan skill karyawan.

f. Melihat prospek usaha anggota kedepannya.

\section{KESIMPULAN}

Faktor penyebab pembiayaan murabahah bermasalah di KSPPS Perambabulan yaitu terdapat faktor internal dan faktor eksternal. Faktor internal yaitu kurang teliti dalam proses analisis calon penerima pembiayaan, kurang maksimal dalam meneliti dan menganalisis berkas, kurangnya komunikasi, 
kurang adanya pengawasan atau survey lebih lanjut dari pihak KSPPS Perambabulan. Sedangkan faktor eksternal yaitu adanya ketidak jujuran dan sikap tidak amanah dari anggota, menurunnya usaha dari anggota, adanya itikad yang tidak baik, anggota yang menunda-nunda, adanya unsur ketidak sengajaan seperti kebakaran kebanjiran, dan bencana alam lainnya.

Strategi penanganan pembiayaan bermasalah yang digunakan oleh KSPPS Perambabulan adalah Menginformasikan melalui telephone, Memberikan surat peringatan 1, 2, dan 3. Setelah proses Penjadwalan kembali (rescheduling) yaitu degan perpanjangan waktu pembiayaan, Persyaratan ulang (reconditioning) seperti permintaan jaminan kembali. Apabila selama 3 bulan berturut-turut penerima pembiayaan tersebut belum bisa melunasi kewajibannya dalam melakukan pembayaran, maka dari pihak KSPPS Perambabulan akan melakukan eksekusi jaminan.

Upaya-upaya yang dilakukan KSPPS Perambabulan untuk menanggulangi terjadinya pembiayaan yang bermasalah yaitu, wajib melaksanakan SOP dengan benar, Memaksimalkan prinsip 5C (Character, Capacity, Capital, Collateral, Condition), melakukan pemisahan tugas yang memadai, menerapkan prinsip kehatihatian, meningkatkan skill karyawan, dan melihat prospek usaha anggota kedepannya.

\section{DAFTAR PUSTAKA}

Buchori, N. S. (2012). Koperasi Syariah Teori dan Praktik. Banten: PAM Pers.

Irham, A., \& Sholihin. (2010). Pedoman Umum Keuangan Syariah. Jakarta: PT. Gramedia Pustaka Utama.

Kasmir. (2002). Dasar-Dasar Perbankan. Jakarta: PT. Raja Grafindo Persada.

Kasmir. (2009). Analisis Laporan Keuangan. Jakarta: PT. Raja Grafindo Persada.

Khasmir. (2013). Bank dan Lembaga Keuangan Lainnya. Jakarta: PT. Raja Grafindo Persada.

Majid, A. (2015). Analisis Penanganan Pembiayaan Murabahah Bermasalah Di BMT EL Amanah Kendal.
Universitas Islam Negeri Walisongo

Semarang, Semarang.

Meleong, L. J. (2002). Metodologi Penelitian Kualitatif. Bandung: PT. Remaja Rosadakarya.

Nasrullah, M. (2017). Strategi Penyelesaian Pembiayaan Murabahah Bermasalah

Di Koperasi Simpan Pinjam dan Pembiayaan Syariah Bina Insan Mandiri (KSPPS BIM) Gondangrejo Karanganyar. Universitas Muhammadiyah Surakarta, Surakarta.

Novitasari, N. (2016). Analisis Penanganan Pembiayaan Bermasalah Pada Akad Murabahah Di BMT Al-Hikmah Ungaran Cabang Gunungpati. Universitas Islam Negeri Walisongo Semarang, Semarang.

Rahayu, A. F. (2018). Strategi Penanganan Pembiayaan Bermasalah Pada Produk Pembiayaan Murabahah Di KSPPS BMT Walisongo Semarang. Universitas Islam Negeri Walisongo Semarang, Semarang.

Sugiyono. (2012). Metode Penelitian Kuantitatif, Kualitatif, dan $R \& D$. Bandung: CV. Alfabeta.

Sutedi, A. (2009). Perbankan Syariah (tinjauan dan beberapa segi hukum). Jakarta: Ghalia Indonesia.

Tanjung, I. F. (2015). Penanganan Pembiayaan Bermasalah Di BMT Amanah Mulia Magelang. Universitas Islam Negeri Walisongo Semarang, Semarang.

Tika, M. P. (2006). Metodologi Riset Bisnis. Jakarta: PT. Bumi Aksara.

Yaya, R., \& Erlangga, A. (2014). Akuntansi Perbankan Syariah. Jakarta: Salemba Empat.

Z, A. W. (2012). Pembiayaan Bank Syariah. Jakarta: PT. Gramedia Pustaka. 